\title{
ERRATA 1
}

In the article "The impact of Cabanis reform on medical education in Brazil: an essay in neo-Foucauldian archeology" (http://dx.doi.org/10.1590/S0104-59702019000200002), published in volume 26, issue 2, Apr.-Jun. 2019:

- On page 1, where it reads: "The impact of the Cabanis reform on medical education in Brazil: an assessment of neo-Foucauldian archeology",

- it should read: "The impact of Cabanis reform on medical education in Brazil: an essay in neo-Foucauldian archeology".

- On page 1, where it reads: "ALMEIDA-FILHO, Naomar. The impact of the Cabanis reform on medical education in Brazil: an assessment of neo-Foucauldian archeology. História, Ciências, Saúde - Manguinhos, Rio de Janeiro, v.26, n.2, abr.-jun. 2019. Available at: $<$ http://www.scielo.br/hcsm>.",

- it should read: "ALMEIDA-FILHO, Naomar. The impact of Cabanis reform on medical education in Brazil: an essay in neo-Foucauldian archeology. História, Ciências, Saúde - Manguinhos, Rio de Janeiro, v.26, n.2, abr.-jun. 2019. Available at: <http://www.scielo.br/hcsm>.".

- On page 1, where it reads: "This text assesses the impact of the Cabanis reform on the formation of the health training model which became hegemonic in Brazil. First, we shall briefly discuss the process of constructing the social, ideological, and institutional framework for healthcare in post-revolutionary France. Next the main elements of the Cabanis reform are introduced, analyzing curricular and pedagogical aspects of the new plan for medical education based on professionalism, disciplines, and expertise that resulted in a system of higher education without universities. This is followed by assessment of the historical process which resulted in the "Francization" of the Brazilian educational system, particularly in higher education and more specifically medical education, producing a model of health training based on colleges, hospitals, classrooms, disciplines, skills, and diplomas.",

- it should read: "This text assesses the impact of Cabanis reform on the formation of the health training model which became hegemonic in Brazil. First, we shall discuss the process of constructing the social, ideological, and institutional framework for healthcare in post-revolutionary France. Next the main elements of Cabanis reform are introduced, analyzing curricular and pedagogical aspects of the new plan for medical education based on professionalism, disciplines, and expertise that resulted in a system of higher education without universities. This is followed by assessment of the historical process 
which resulted in the "Francization" of the Brazilian educational system, producing a model of health training based on faculties, hospitals, lectures, disciplines, specialties, and diplomas.".

- On pages 2-4, where it reads:

"In Michel Foucault's writings on medicine and health, Pierre-Jean Georges Cabanis (1757-1808) is without a doubt a central character. ${ }^{1}$ At various points in his historiographic work, Foucault $(1961,1963)$ expresses his respect and admiration for Cabanis, who is recognized as a "genius," the intellectual precursor of technological and scientific modernity, an efficient political operator, creative reformer, and thinker who is indispensable for understanding nineteenth-century French philosophical, scientific, and cultural hegemony. And yet, as I have addressed elsewhere (Almeida-Filho, 2017), Foucault pays little attention to Cabanis's role as a reformer of medical education; he was principally interested in ways of standardizing health and disease, reorganization of the health care network, and regulation of the new care practices which emerged after the French Revolution.

During the first phase of his work, a meticulously critical history of the human sciences, medicine, and madness, Foucault $(1961,1963,1966)$ postulates a conceptual and analytical approach he designates as the "archeology of knowledge." Within this reference, arrays of thought (epistemes or rationalities) organize human knowledge based on normativities, through rules of logic and language structures that either unconsciously or as habitus govern individual behavior and social practices as a system of positivity which retrain and configure discursive formations within a certain time and place (Foucault, 1969).

At the conceptual level, Foucault's notion of archeology connects to a historical epistemology based on discontinuities, following the path blazed by Canguilhem (2009). At the methodological level, in line with the evidential paradigm (Ginzburg, 1989), Foucault proposes the concept of "archive" as a corpus, a set of discourse manifested as historical data, narratives, documents, and other records, to be treated as devices to organize discursive operations in order to construct social representations and the production of social practices within a given culture or time. From this referential, we consider four points as an analytical matrix: (a) ruptures: critical moments and points in space and time that indicate historical discontinuities; (b) latencies: origins, fossils, myths, absences, and especially persistent shortcomings; (c) details: prospecting of signs, evidence, and indications, including hidden or camouflaged signals; (d) icons: characters or events (individual or collective) which represent or are significant for a certain time or historical process, without reducing historical analysis to the study of people, facts, accomplishments, and dates.

With the proper adjustments (considering the limits and restricted objectives of this text), we take this approach as a framework for a social history of health demarcated by discontinuities. This perspective allows the identification of three ruptures in matrices of knowledge and care practices in western culture: Hippocratic naturalism, which was incorporated into Aristotelian thought and reclaimed by Arabic medicine in the tenth century; Enlightenment rationalism, which was advocated by modern reformers at the turn of the 
nineteenth century; and applied technical and scientific pragmatism in the early twentieth century. Linking models of health care training and modes of care, these ruptures correspond to Avicenna, Cabanis, and Flexner, respectively.

In another text (Almeida-Filho, 2010) I analyzed the Flexner rupture, particularly its imaginary and nearly mythological resonance within the social and political discourse about health in the Brazilian context. ${ }^{2}$ Recently, when discussing Cabanis's role as a reformer of modern medical education, I formulated a preliminary hypothesis on the roots of higher education in Brazil (Almeida-Filho, 2017, p.13):

Brazilian higher education displays curious archeological signs, since it hegemonically preserves the institutional arrangements of colleges and cultivates the nominal concept of university, with students directly entering professional degree courses founded on curricular structures that tend to be fixed, organized by blocks of content called disciplines or subjects, which in turn are within the institutional and politicalpedagogical model established during the Cabanis reform. ${ }^{3}$

Here, from the perspective we can call neo-Foucauldian archeology, ${ }^{4}$ I propose a more detailed assessment of this hypothesis, evaluating the direct and indirect effects of the Cabanis reform in configuring the health education model which became hegemonic in Brazil. To this end, I will first briefly discuss the process of constructing the social, ideological, and institutional framework that restructured the healthcare model in postrevolutionary France. Next, I introduce the main structural elements of the Cabanis reform, analyzing curricular and pedagogical aspects of proposed medical education based on professionalism, disciplines, and expertise that resulted in a system of higher education without universities. Then I will assess the sequence of events and processes which (throughout the nineteenth century and the first half of the twentieth century) promoted the "Francization" of the Brazilian educational system, particularly in higher education and more specifically medical education, which was the origin of the current model of health training based on colleges, hospitals, classrooms, disciplines, skills, and diplomas.

\section{Context and background}

After the Renaissance, a model of higher education was established across the entire western world to train professionals for new social functions in the fields of applied technology such as mining, commerce, engineering, education, and health, as well as secular managers for the modern state. Large universities, the ivory towers dominated by the aristocratic intellectual elite and governed by royalty, did not suppress the scholastic tradition and resisted the advance of modern sciences (Weisz, 1983). During the second half of the eighteenth century, the university began to face a serious identity crisis as a new mode of production emerged, previously subaltern social classes ascended, and new forms of government were configured (Charle, Verger, 1996). The Germanic solution to this crisis was the Humboldt reform, an active renovation of original university values as a strategic political concept and civilizing device (at least from a capitalist, Eurocentric viewpoint) which proposed the connection between teaching and research as a defining element of universities (Backhaus, 2015). 
The French Revolution yielded a different solution, which was more political than cultural: the summary elimination of academies and universities. When it closed the French universities in 1793, the National Assembly signaled that the French Republic urgently needed educational institutions for the political, scientific, and professional training of free citizens (Barnard, 1969). At this time there was enormous inequality and social segregation in French healthcare (Weisz, 1983; Brockliss, Jones, 1997). The poor population had access to care provided by barber-surgeons and apothecaries, who generally received their training in master/apprentice relationships. Hospitals were managed by religious orders and were places to house the dying, insane asylums, provided lodging for travelers and vagabonds, and often also served as political prisons, with little function as places for care and healing. ${ }^{5}$ The aristocracy was served by clinicians (physicians) or surgeons who provided health services of dubious effectiveness which were limited to these grand families and the courts. According to Weisz (1983, p.20), these physicians were generally trained in one of the 18 credentialed schools of medicine or surgery in all of France (only three of which were linked to universities).

In 1790, Felix Vicq d'Azyr (1748-1794), surgeon to the court of Louis XVI, presented the National Assembly with a Nouveau plan de constitution pour la médecine en France. Its main emphasis was the definitive unification of medicine and surgery, formally overcoming a schism that dated back to the Middle Ages. His proposal also combined human and veterinary medicine, defined diagnosis as the result of anatomopathological correlation of clinical findings, and specified that hospitals should have salles d'autopsie and that all deaths should be investigated by accredited anatomists (Schmitt, 2009). As for medical education, he proposed a single chair uniting anatomy and physiology, integrating structure and process through methodological justification. In his Encyclopédie méthodique, d'Azyr (quoted in Rey, 1993, p.38) wrote: "Anatomy alone is the skeleton of science, so to speak; what provides its movement is physiology: one is the study of life, the other is only the study of death."

The scientific contribution of this talented anatomist was exceptional. ${ }^{7}$ His understanding of method and analysis developed to justify the scientific foundations of comparative anatomy allowed his intellectual successor, the young doctor Xavier Bichat (1771-1802), to revolutionize physiology and its relationship with pathology by introducing the concept of tissue, which gave rise to modern morphological sciences within the new scientific discipline of histology (Staum, 1980). The Nouveau plan served as the basis for all proposals to reform medicine, in institutional organization, modes of care, and teaching models, and the active presence of Cabanis was essential as a proponent, manager, and political operator on all fronts (Foucault, 1963).

A 1791 report from the Comité des Hôpitaux proposed the creation of a state-controlled health system, closing large hospitals and deploying a network of small establishments. Additionally, in practical terms, a medical policy (police médicale) would be needed, along with a code of health and a state examination for foreign doctors and health professionals trained outside of the colleges (Cabanis, 1798c, p.91). Foucault (1963) reports that when general legislation on medical practice was finally approved in 1802, all these suggestions had been incorporated. In this way, a rapid historic process established an institutional healthcare arrangement which emerged organically among the new economic, social, and political 
order introduced by the bourgeois revolution in France, with profound transformations in the organization of services, health legislation, and medical practice, as well as obligatory professional certification through a diploma obtained from institutions of higher education.",

- it should read:

"In Michel Foucault's writings on medicine and health, Pierre-Jean Georges Cabanis (1757-1808) is without a doubt a central character. ${ }^{1}$ At various points in his historiographic work, Foucault $(1961,1963)$ expresses his respect and admiration for Cabanis, who is recognized as a "genius," the intellectual precursor of technological and scientific modernity, an efficient political operator, creative reformer, and thinker who is indispensable for understanding nineteenth-century French philosophical, scientific, and cultural hegemony. And yet, as I have addressed elsewhere (Almeida-Filho, 2017), Foucault pays little attention to Cabanis's role as a reformer of medical education; he was principally interested in ways of standardizing health and disease, reorganization of the health care network, and regulation of the new care practices which emerged after the French Revolution.

During the first phase of his work, a meticulously critical history of the human sciences, medicine, and madness, Foucault $(1961,1963,1966)$ postulates a conceptual and analytical approach he designates as the "archeology of knowledge." Within this reference, arrays of thought (epistemes or rationalities) organize human knowledge based on normativities, through rules of logic and language structures that either unconsciously or as habitus govern individual behavior and social practices as a system of positivity which define boundaries and configure discursive formations within a certain time and place (Foucault, 1969).

At the conceptual level, Foucault's notion of archeology connects to a historical epistemology based on discontinuities, following the path blazed by Canguilhem (2009). At the methodological level, in line with Carlo Ginzburg's paradigma indiziario, ${ }^{2}$ Foucault proposes the concept of "archive" as a corpus, a set of discourse manifested as historical data, narratives, documents, and other records, to be treated as devices to organize discursive operations in order to construct social representations and the production of social practices within a given culture or time. From this frame of reference, we consider four points as an analytical matrix: (a) ruptures: critical moments and points in space and time that indicate historical discontinuities; (b) latencies: origins, fossils, myths, absences, and especially persistent shortcomings; (c) details: prospecting of clues, signs, and traces, including hidden or camouflaged signals; (d) icons: characters or events (individual or collective) which represent or are significant for a certain time or historical process, without reducing historical analysis to the study of persons, facts, accomplishments, and dates.

With the proper adjustments (considering the limits and restricted objectives of this text), we take this approach as a framework for a social history of health demarcated by discontinuities. This perspective allows the identification of three ruptures in matrices of knowledge and care practices in western culture: Hippocratic naturalism, which was incorporated into Aristotelian thought and reclaimed by Arabic medicine in the tenth century; Enlightenment rationalism, which was advocated by modern reformers at the 
turn of the nineteenth century; and applied technical and scientific pragmatism in the early twentieth century. Linking models of education and modes of health care, these ruptures correspond to remarkable historical personalities who became icons: Avicenna, Cabanis, and Flexner, respectively.

In another text (Almeida-Filho, 2010) I analyzed the Flexner rupture, particularly its imaginary and nearly mythological resonance within the social and political discourse about health in the Brazilian context. ${ }^{3}$ Recently, when discussing Cabanis's role as a reformer of modern medical education, I formulated a preliminary hypothesis on the roots of higher education in Brazil (Almeida-Filho, 2017, p.13):

Brazilian higher education displays curious archeological signs, since it hegemonically preserves the institutional arrangements of faculties and cultivates the nominal concept of university, with students directly entering professional degree courses founded on curricular structures that tend to be fixed, organized by blocks of content called disciplines or subjects, which in turn are within the institutional and politicalpedagogical model established during the Cabanis reform. ${ }^{4}$

In this paper, from the perspective we can call neo-Foucauldian archeology, ${ }^{5}$ I propose a more detailed assessment of this hypothesis, evaluating the direct and indirect effects of the Cabanis reform in configuring the health education model which became hegemonic in Brazil. To this end, I will first briefly discuss the process of constructing the social, ideological, and institutional framework that restructured the healthcare model in postrevolutionary France. Next, I introduce the main structural elements of the Cabanis reform, analyzing curricular and pedagogical aspects of proposed medical education based on professionalism, disciplines, and specialization that resulted in a system of higher education without universities. Then I will assess the sequence of events and processes which (throughout the nineteenth century and the first half of the twentieth century) promoted the "Francization" of the Brazilian educational system, particularly in higher education and more specifically medical education, which was the origin of the current model of health training based on faculties, hospitals, lectures, disciplines, specialties, and diplomas.

\section{Context and background}

After the Renaissance, a model of higher education was established across the entire western world to train professionals for new social functions in the fields of applied technology such as mining, commerce, engineering, education, and health, as well as secular managers for the modern state. Large universities, the ivory towers dominated by the aristocratic intellectual elite and governed by royalty, did not suppress the scholastic tradition and resisted the advance of modern sciences (Weisz, 1983). During the second half of the eighteenth century, the university began to face a serious identity crisis as a new mode of production emerged, previously subaltern social classes ascended, and new forms of government were configured (Charle, Verger, 1996). The Germanic solution to this crisis was the Humboldt reform, an active renovation of original university values as a strategic political concept and civilizing device (at least from a capitalist, Eurocentric 
viewpoint) which proposed the connection between teaching and research as a defining element of universities (Backhaus, 2015).

The French Revolution yielded a different solution, which was more political than cultural: the summary elimination of academies and universities. By suppressing the universities in 1793, the National Assembly signaled that the French Republic urgently needed educational institutions for the political, scientific, and professional training of free citizens (Barnard, 1969). At this time there was enormous inequality and social segregation in French healthcare (Weisz, 1983; Brockliss, Jones, 1997). The poor population had access to care provided by barber-surgeons and apothecaries, who generally received their training in master/apprentice relationships. Hospitals were managed by religious orders and were places to house the dying, insane asylums, provided lodging for travelers and vagabonds, and often also served as political prisons, with little function as places for care and healing. ${ }^{6}$ The aristocracy was served by clinicians (physicians) or surgeons who provided health services of dubious effectiveness which were limited to these grand families and the courts. According to Weisz (1983, p.20), these physicians were generally trained in one of the 18 credentialed schools of medicine or surgery in all of France (only three of which were linked to universities).

In 1790, Felix Vicq d'Azyr (1748-1794), surgeon to the court of Louis XVI, presented the National Assembly with a Nouveau plan de constitution pour la médecine en France. Its main emphasis was the definitive unification of medicine and surgery, formally overcoming a schism that dated back to the Middle Ages. His proposal also combined human and veterinary medicine, defined diagnosis as the result of anatomopathological correlation of clinical findings, and specified that hospitals should have salles d'autopsie and that all deaths should be investigated by accredited anatomists (Schmitt, 2009). As for medical education, he proposed a single chair uniting anatomy and physiology, providing a methodological rationale for the integration of structure and process. In his Encyclopédie méthodique, d'Azyr (quoted in Rey, 1993, p.38) wrote: "Anatomy alone is the skeleton of science, so to speak; what provides its movement is physiology: one is the study of life, the other is only the study of death."

The scientific contribution of this talented anatomist was exceptional. ${ }^{8}$ His understanding of method and analysis developed to justify the scientific foundations of comparative anatomy allowed his intellectual successor, the young doctor Xavier Bichat (1771-1802), to revolutionize physiology and its relationship with pathology by introducing the concept of tissue, which gave rise to modern morphological sciences within the new scientific discipline of histology (Staum, 1980). The Nouveau plan served as the basis for all proposals to reform medicine, in institutional organization, modes of care, and teaching models, and the active presence of Cabanis was essential as a proponent, manager, and political operator on all fronts (Foucault, 1963).

A 1791 report from the Comité des Hôpitaux proposed the creation of a state-controlled health system, closing large hospitals and deploying a network of small establishments. Additionally, in practical terms, a medical policy (police médicale) would be needed, along with a code of health and a state examination for foreign doctors and health professionals trained outside of the faculties (Cabanis, 1798c, p.91). Foucault (1963) reports that when general legislation on medical practice was finally approved in 1802, all these suggestions 
had been incorporated. In this way, a rapid historic process established an institutional healthcare arrangement which emerged organically among the new economic, social, and political order introduced by the bourgeois revolution in France, with profound transformations in the organization of services, health legislation, and medical practice, as well as obligatory professional certification through a diploma obtained from institutions of higher education.".

- On pages 5-7, where it reads:

\section{“Medical schools vs. écoles de santé}

At the end of the period that Foucault designates as the Classical Era, medical training in France was precarious and chaotic. There were low-quality medical schools where department chairs were disputed by declining nobility as a secure source of income, since only chaired professors could charge for vocational education. Foucault (1963, p.48) also reports that apprentices needed to shadow "a renowned doctor who must also be compensated" 8 on home visits and hospital rounds, as well as pay dearly to prepare for and take qualifying examinations. Brockliss (1998, p.71), the doyen of British historians specializing in the French Revolution, critically evaluates the training requirements which existed in French schools in the eighteenth century:

On the one hand, the system was marred by corruption in that professors were lazy and degrees were awarded without a proper examination of the candidate's knowledge. On the other, and the two were not unconnected, the curriculum of medical faculties was completely inadequate as a training for medical practice.

As we have seen, to overcome this situation inherited from the Ancien Régime the agenda of the political leaders of the French Revolution included radical measures such as eradicating scientific societies, corporations, and guilds, closing academies, universities, and colleges, and approving plans for institutional reform (Foucault, 1963, p.73). These measures were complemented by two medium- and long-term strategies: make professional medical practice dependent on state-accredited medical instruction while reorganizing the system of health education itself.

In 1792, Antoine-François de Fourcroy (1755-1809), d'Azyr's intellectual successor, presented the Convention with a proposal to rebuild the French system of higher education in health based on "free teaching of the sciences and arts." In concrete terms, he postulated massive restructuring of education based on "free medicine," replacing medical colleges with écoles de santé (Fourcroy, 1793). In addition to integrating medicine and surgery, he proposed including pharmacy and public administration as fundamental subjects for more effective training. The écoles de santé were expected to recruit young students with "good conduct, pure habits, love of the Republic and hate of tyrants, careful education, to ensure that students have the initial elements of the exact sciences, and, above all, cultivation of certain sciences which serve as preliminary to the art of healing" (Fourcroy, 1793, p.1213). ${ }^{9}$ Foucault $(1963$, p.74) comments that instead of empty physiology, the new school of health was designed to teach the art of healing from a practical and socially-engaged 
perspective, quite unlike the old schools of medicine which were home to knowledge that was "ésotérique et livresque."

Without details related to the curriculum or pedagogy, Fourcroy's proposal was neither a consistent theoretical text nor a systematic technical document; rather, it was more political libel, with its somber and dramatic tone describing the precarious health situation and the chaos of medical practice during the monarchic period, but contained triumphalist rhetoric in presenting solutions designed to overcome the inherited problems (Fourcroy, 1793). Within the dimension of pedagogy, even a brief presentation already included an integrated perspective on medical training which proposed replacing the old rhetoric with didactic solutions based on laboratory practice, reconfigured by chemical experiments. Despite some differences Vicq d'Azyr supported the proposal, negotiating a middle position that permitted integration between the fundamental clinical subjects and emphasized comparative anatomy, physiology, and pharmaceutical chemistry as major curricular lines. The d'Azyr-Fourcroy plan earned broad support and was approved in February 1794; it was expanded to two more schools of health in the provinces, in Montpellier and Strasbourg, which were traditional centers of medical education (Rosen, 1946).

The first école de santé was established in Paris in a building described as monumental, which had originally been intended to be a medical-surgical academy that was decommissioned by the Revolution. Despite this satisfactory physical location, training would take place in the network of hospitals recently established by the comite chaired by Thouret, who was appointed the first dean of the new school. The project included three classes of regular students (officiers de santé, chirurgiens, médecins), as well as auditing students (auditeurs libres). Each student's class was defined by public examinations, which varied in content: anatomy, operations and dressings, and medical-surgical subjects for students pursuing a degree in surgery, and anatomy and physiology, the medical field, and the natural history of internal and external diseases if the candidate planned to obtain a degree in medicine. The training also varied in duration: three years for officier de santé, four years for chirurgien, and five years for médecin. Graduates who wished to continue into a career in medicine not only needed to pass their exams but also defend a thèse de doctorat (Rey, 1993).

The title officier de santé, a key element of the proposal, emphasized a practical notion of positive health (even if this was still in its infancy) and may have been positively received in the beginning because it helped overcome the traditional distinction between physicians and surgeons. It also was seen to be in line with the Republican concept of health care as a right of all men and women, which was established in the 1791 Constituent Assembly. The proposal replicated military organization, with a uniform and career hierarchy that would theoretically facilitate social acceptance within a wartime context. At the turn of the nineteenth century, France had 3,309 officiers de santé who had been trained in different institutions. At that time, after three years of operation, the écoles de santé already had 4,027 students registered; 406 of these were thésards and consequently candidates for medicine (Rey, 1993).

What about broad access to university education, which had previously been reserved for the elites, by candidates from the lower classes? General professional education based on training citizens in politics, art, philosophy, and science? Free, active, and 
supported higher education instead of "Gothic universities and academic aristocracies"? Or training health professionals in schools of health rather than specialists in morbidity in schools of disease, which from their origin to this day are known as "medical schools"? Teaching-learning process based on scientific evidence, from anatomical and clinical connections derived from diagnostic correlations and pharmaceutical-chemical-surgical links to define therapeutic strategies? Interdisciplinary avant la lettre within the curricular structure and integration into training processes, connecting theory and practice in real training contexts? The political relevance and modern importance of these questions that comprised the first agenda for health education reform during the French Revolution are truly remarkable.

In practice, the d'Azyr-Fourcroy plan suffered strategic setbacks that compromised its continuity, mainly due to the establishment of a professional corporation model which was organically connected to the Republican political network. Foucault (1963) notes the rapid decline of the institutional model of the écoles de santé, while Crosland (2004) analyzes the semantic changes in the use of the term officier de santé as indicating the failure of the model. There are three explanations for these parallel processes: first, in the early years of the Revolution the freedom to describe oneself resulted in many unqualified professionals and even quacks working in health care without any oversight; second, during the Convention, professional corporations resurfaced strongly and pressed for a return to their former roles; third, academies and scientific societies returned to political activity and began to fight to fully reopen the colleges.

In 1797, the Societé de Santé de Paris, which had been founded by the physicians who formed the faculty of the health schools, was renamed the Sociéte de Médecine. By the turn of the nineteenth century, all the institutions of medical education had abandoned the title école de santé in favor of the more traditional faculté (or école) de médecine. During the Napoleonic standardization of medical practice in 1802, the title officier de santé was only used for those who had received shorter and simplified training to provide care in the army; with these limited attributes, this group was discriminated against in the provinces as second-class health professionals.",

- it should read:

\section{“Medical schools vs. écoles de santé}

At the end of the period that Foucault designates as the Classical Era, medical training in France was precarious and chaotic. There were low-quality medical schools where chaises (chairs) were disputed by the decaying nobility as a secure source of income, since only chaired professors could charge for vocational education. Foucault $(1963$, p.48) also reports that apprentices needed to shadow "a renowned doctor who must also be compensated" 9 on home visits and hospital rounds, as well as pay dearly to prepare for and take qualifying examinations. Brockliss (1998, p.71), a leading scholar among British historians specializing in the French Revolution, critically evaluates the training requirements which existed in French schools in the eighteenth century: 
On the one hand, the system was marred by corruption in that professors were lazy and degrees were awarded without a proper examination of the candidate's knowledge. On the other, and the two were not unconnected, the curriculum of medical faculties was completely inadequate as a training for medical practice.

As we have seen, to overcome this situation inherited from the Ancien Régime the agenda of the political leaders of the French Revolution included radical measures such as eradicating scientific societies, corporations, and guilds, closing academies, universities, and faculties, and approving plans for institutional reform (Foucault, 1963, p.73). These measures were complemented by two medium- and long-term strategies: make professional medical practice dependent on state-accredited medical instruction while reorganizing the system of health education itself.

In 1792, Antoine-François de Fourcroy (1755-1809), d'Azyr's intellectual successor, presented the Convention with a proposal to rebuild the French system of higher education in health based on "free teaching of the sciences and arts." In concrete terms, he postulated massive restructuring of education based on "medicine for freedom," replacing medical faculties with écoles de santé (Fourcroy, 1793). In addition to integrating medicine and surgery, he proposed including pharmacy and public administration as fundamental subjects for more effective training. The écoles de santé were expected to recruit young students with "good conduct, pure habits, love of the Republic and hate of tyrants, careful education, to ensure that students have the initial elements of the exact sciences, and, above all, cultivation of certain sciences which serve as preliminary to the art of healing" (Fourcroy, 1793, p.12-13). ${ }^{10}$ Foucault (1963, p.74) comments that instead of empty physiology, the new school of health was designed to teach the art of healing from a practical and socially-engaged perspective, quite unlike the old schools of medicine which were home to knowledge that was "ésotérique et livresque."

Without details related to the curriculum or pedagogy, Fourcroy's proposal was neither a consistent theoretical text nor a systematic technical document; rather, it was more political libel, with its somber and dramatic tone describing the precarious health situation and the chaos of medical practice during the monarchic period, but contained triumphalist rhetoric in presenting solutions designed to overcome the inherited problems (Fourcroy, 1793). Within the dimension of pedagogy, even as a brief presentation, he already included an integrated perspective on medical training which proposed replacing the old rhetoric with didactic solutions based on laboratory practice, reconfigured by chemical experiments. Despite some differences, Vicq d'Azyr supported the proposal, negotiating a middle position that permitted integration between the fundamental clinical subjects and emphasized comparative anatomy, physiology, and pharmaceutical chemistry as major curricular lines. The d'Azyr-Fourcroy plan earned broad support and was approved in February 1794; it was expanded to two more schools of health in the provinces, in Montpellier and Strasbourg, which were traditional centers of medical education (Rosen, 1946).

The first école de santé was established in Paris in a building described as monumental, which had originally been intended to be a medical-surgical academy that was decommissioned by the Revolution. Despite this satisfactory physical location, training would take place in the network of hospitals recently established by the Comité des Hôpitaux chaired by Thouret, 
who was appointed the first dean of the new school. The project included three classes of regular students (officiers de santé, chirurgiens, médecins), as well as auditing students (auditeurs libres). Each student's class was defined by public examinations, which varied in content: for students pursuing a degree in surgery, anatomy, operations and dressings, and medicalsurgical subjects; if the candidate planned to obtain a degree in medicine, anatomy and physiology, materia medica, and the natural history of internal and external diseases. The training also varied in duration: three years for officier de santé, four years for chirurgien, and five years for médecin. Graduates who wished to continue into a career in medicine not only needed to pass their exams but also defend a thèse de doctorat (Rey, 1993).

The title officier de santé, a key element of the proposal, emphasized a practical notion of positive health (even if this was still in its infancy) and may have been positively received in the beginning because it helped overcome the traditional distinction between physicians and surgeons. It also was seen to be in line with the Republican concept of health care as a right of all men and women, which was established in the 1791 Constituent Assembly. The proposal replicated military organization, with a uniform and career hierarchy that would theoretically facilitate social acceptance within a wartime context. At the turn of the nineteenth century, France had 3,309 officiers de santé who had been trained in different institutions. At that time, after three years of operation, the écoles de santé already had 4,027 students registered; 406 of these were thésards and consequently candidates for medicine (Rey, 1993).

What about broad access to university education, which had previously been reserved for the elites, by candidates from the lower classes? General professional education based on training citizens in politics, art, philosophy, and science? Free, active, and supported higher education instead of "Gothic universities and aristocratic academies?" Or training health professionals in schools of health rather than specialists in morbidity in schools of disease, which from their origin to this day are known as "faculties of medicine?" Teachinglearning process based on scientific evidence, from anatomical and clinical connections derived from diagnostic correlations and pharmaceutical-chemical-surgical links to define therapeutic strategies? Curricular structure and integration into training processes, both interdisciplinary avant la lettre, connecting theory and practice in real training contexts? The political relevance and modern importance of these questions that comprised the first agenda for health education reform during the French Revolution are truly remarkable.

In practice, the d'Azyr-Fourcroy plan suffered strategic setbacks that compromised its continuity, mainly due to the establishment of a professional corporation model which was organically connected to the Republican political network. Foucault (1963) notes the rapid decline of the institutional model of the écoles de santé, while Crosland (2004) analyzes the semantic changes in the use of the term officier de santé as indicating the failure of the model. There are three explanations for these parallel processes: first, in the early years of the Revolution the freedom of self-appointment resulted in many unqualified professionals and even quacks working in health care without any oversight; second, during the Convention, professional corporations resurfaced strongly and pressed for a return to their former roles; third, scientific societies returned to political activity and began to fight for fully reopening faculties and academies. 
In 1797, the Societé de Santé de Paris, which had been founded by physicians who formed the professoriate of the health schools, was renamed as Société de Médecine. By the turn of the nineteenth century, all medical education institutions had abandoned the title école de santé in favor of the more traditional faculté (or école) de médecine. During the Napoleonic standardization of medical practice in 1802, the title officier de santé was only used for those who had received shorter and simplified training to provide care in the army and, with limited attributes, in the provinces. For these reasons, this group suffered discrimination as second-class health professionals.".

- On pages 7-11, where it reads:

\section{"The Cabanis reform}

The failure of the Fourcroy plan created an opportunity for colleges to reemerge without central control by the universities, culminating in the segmentation and isolation (or, as some said, elitization) of medical practice. Cabanis took advantage of his work as a teacher at the École de Santé de Paris and his position as a representative in the Council of 500, as well as a member of the Comite d'Instruction Publique, affirming the importance of the intellectual and political framework within this process. Under his active leadership, a set of proposals, documents, acts and standards were prepared, proposed and approved; with a certain historical detachment, I have proposed calling this set of developments the Cabanis reform (Almeida-Filho, 2017).

As an "archive" in the Foucauldian sense, the Cabanis reform unfolds in various texts, generally documents and reports which were submitted to and read before committees and legislative bodies: Observations sur les hôpitaux (1790); Travail sur l'éducation publique, trouvé dans les papiers de Mirabeau l'aîné (1791); Considérations genérales sur les révolutions de l'art de guérir (1795); Opinion sur le projet d'organisation des écoles primaires et en general sur l'instruction publique (1956a); Projet de résolution, sur un mode provisoire de police médicale (1798c); Rapport fait au Conseil des Cinq-Cents sur le mode d'organisation des écoles de médecine (1798b); Quelques principes et quelques vues sur les secours publics (1956b). Some of these texts were gathered into thematic volumes, edited, and published as books: Rapports du physique et du moral de l'homme (1802); Coup d'oeil sur les revolutions et réforme de la médecine (1823).

As a general proposition, the Cabanis reform comprised five elements:

(1) an organizational model of higher education divided into colleges;

(2) medical education which was primarily professional in nature, with more technical than scientific or cultural training;

(3) hospital-centered training based on interventionism;

(4) linear-progressing curricula geared toward disciplines;

(5) analytic pedagogical strategy separated by professions and restricted areas, tending toward specialization.

As I detailed elsewhere (Almeida-Filho, 2017), within the Cabanis reform medical education would take place in independent schools, with the greatest possible autonomy from the central university body. Starting with the process of secularizing hospitals, new learning spaces were adapted to a clinical practice founded on systematic nosological 
knowledge. Instead of the master/apprentice relationship which was specific to the artisanal clinical training of that time, the Cabanis reform made instruction in hospitals compulsory, with the invention of the internship (internat des hôpitaux) and later, medical residencies. At the end of the course, the institution would grant its graduates a university diploma which was formally recognized and became a legal device allowing bearers to practice medicine and surgery as professionals. This was the basis for the hospital-centric and interventionist training that became dominant in medical education starting from the nineteenth century.

In general, the Cabanis reform sought an organic link between philosophy, medicine, education, and politics, expressed in the "association of medical knowledge and analysis with a political project" (Saad, 2016, p.29), in an attempt to harmonize solutions which were at times contradictory or at least derived from conceptually different models. With Mirabeau, alongside the iconic rejection of Latin as a scientific lingua franca, the new goal was to surpass the university as a concept and as a coordinating body, creating a decentralized institutional structure based on individual colleges and schools. Like Condorcet, the plan defended the recovery of the academies and scientific societies proscribed by the 1789 Revolution. Of the Thouret-Pinel-Cabanis plan, hospitals were to be reorganized into wards by morbidity classification, making them suitable instruction spaces to study and comparatively demonstrate cases. From the d'Azyr-Fourcroy plan, the therapeutic orientation of pharmaceutical chemistry was easily incorporated into a condensing of medicine, surgery, and pharmacy, accepting the field of comparative anatomy as the methodological axis of the basic sciences. From the epistemological agenda of the Idéologie, which Cabinis himself actively worked to construct, was added the elements of moral philosophy needed to mold the politically engaged citizen who also comprised the new profile of the doctor, which at that time was recommended to solidify (and perhaps overcome) the liberal agenda of the bourgeois revolution.

Conceptually, the reform's references included the naturalist philosophies and life sciences which were emerging in the first moments of modernity, adopting a semiotic theory of the clinic that consisted of physiology, pathology, and therapy. Scientific knowledge would be deconstructed and reconstructed according to Cartesian linear order, from the simplest to the most complex subject, in an exhaustive and encyclopedic operation. The new curricular structure would be based on interdisciplinarity, with the knowledge broken down into its essential parts: the disciplines (or subjects), within the cognitive dimension, equivalent to the concept of a department chair within the dimension of institutional organization. Analytical pedagogy guided by divisions into disciplines implied fragmentation, analysis, and subsequent reordering of blocks of content, modes of practice, and especially knowledge, which were memorized, stored, coded, and classified according to the prevailing scientific doctrines. The disciplines were to be precisely differentiated, and for reform of the medical education curriculum, grouped into natural history (basic sciences), medical subjects (clinical and therapeutic sciences), and moral sciences. The main consequence this disciplinary model of curricular organization had on modes of health care was fragmentation of the practice (initially surgical, and later clinical) into medical specialties. In this sense, the Cabanis reform 
also allowed the tendency to divide and differentiate medical specialties ${ }^{10}$ which divided the still-hegemonic mode of health care.

Within the pedagogical plan, the Cabanis reform meant a radical change in the use of rhetoric, in three aspects: first, it rejected manipulation of rhetoric in pedagogical strategies for training in the field of health, replacing the discourse of authority with greater emphasis on teaching based on experimentation. Second, the Cartesian method justified the systematic fragmentation of the training process as well as the object of the teaching-learning process. In fact, the resulting training model is based on an apology to interdisciplinarity as a way of organizing and cataloging human knowledge into a rational and systematic structure, as advocated by the movement which became famous as Idéologie (Pouliquen, 2013; Saad, 2016). Third, a new rhetoric reordered the logic (in this case, the evidentiary logic) of the formulation of diagnostic reasoning based on signs and symptoms, within the process of constituting the clinical object (Ginzburg, 1989, p.177).

Rosen (1946, p.332), who is most representative among the Anglo-Saxon school of health historians, precisely defined what we call the Cabanis reform: "[the] program of reform and reconstruction in medical education which was initiated and carried out in France during the years between the Thermidorian reaction and the rise of Napoleon." In fact, many of the ideas, solutions, and actions that comprised the Cabanis reform first materialized in the reorganization of the Paris College of Medicine between 1794 and 1800, with Cabanis's active participation. Rosen (1946, p.337) also states that Coup d'oeil included "a program for reform of medical education" which, although it does not explicitly postulate the restoration of medical schools, featured ideas that "do reflect the basic philosophy of the instruction given the students at the Paris medical school." In this framework, Coup d'oeil comprised a study of the history of health and education which targeted the systematization of a new pedagogy needed to reform medical education, which in turn was essential for the sustainability of the desired revolution in French medicine. To a certain extent this text can be considered a pilot plan for a specific part of general educational reform (higher education in the area of health), which in turn was included within an agenda of social reform determined by the backlash of a political revolution, on the edge between Enlightenment and modernity.

The Cabanis reform in fact served as a model for the entire French higher education system, which at that time was structured as a network of isolated higher education institutions such as the Polytechnic School and the Superior Normal School outside the university, which were intended to meet the requirements of the Industrial Revolution and demands for cadres for the state bureaucracy. The only thing lacking to consolidate this vision was a reorganization of the overall framework of the education system in such a way that would replicate a regime free from the old aristocratic order, but one which in fact was not intended to prioritize those segments of society who were poor, oppressed, and exploited by the emerging mode of production. This step would be undertaken by the educational reform promoted by Napoleon Bonaparte, between 1802 and 1806.

Fourcroy returned to the scene at Napoleon's invitation, and from 1802 became the main political operator of Napoleonic educational reform as the General Director of Public Instruction, responsible for approving a general education reform law (Boudon, 2006). 
When Napoleon was crowned emperor of France in 1804, his goal was to implement a strict regime to control the French educational system. To do so, he included the concept of the "imperial university" in his reform program as a body to simultaneously coordinate the teaching network of a given territory as well as a single teaching corps for the entire educational system. ${ }^{11}$

This institutional arrangement consolidated a linear curricular architecture throughout the entire subsystem of French higher education for professional career training through specific, exclusive, and specialized higher education, particularly in the field of health (Charle, Verger, 1996). Against the backdrop of political restoration, this process was quick and intense. In 1814-1815, the three medical colleges in Paris, Montpellier, and Strasbourg already had nearly 1,200 students, while the three schools of pharmacy had around 400 students registered (Boudon, 2007).

During the Third Republic alone, substantial changes in the French higher education system permitted the recovery (albeit partial) of the original idea of the university in France (Liard, 1894). Louis Liard (1846-1917), director of higher education as of 1884, was able to approve a series of decrees granting colleges autonomy to receive financial support, manage resources, and create department chairs and courses (Weisz, 1983; Boudon, 2007). The Liard reform, which was approved by the French Parliament in July 1896, granted legal status to the faculty of the aggregated colleges, which authorized the legal use of the term "university." With this case, the University of Paris-Sorbonne was immediately re-founded in November 1896, followed by the creation of another 15 universities in the interior of the country (Boudon, 2007). Despite its solid arguments and consistent formulation, the Liard reform can be considered a failure; political concessions were forced to approve the reform, and it did not meet its objectives of reclaiming and renovating the concept of the university in France (Charle, Verger, 1996; Prost, 2009).

In the model of higher education which solidified during the Belle Époque, a century after the abolition of the universities by the French Revolution, the college empire remained strong, particularly in the so-called superior colleges (medicine and law) ${ }^{12}$ and the polytechnic schools which trained the professions considered imperial. Within this context, the universities were merely nominal in existence, limited to political mediation and representing a group of colleges with their own political power and administrative and academic autonomy to the state. Despite its limitations, this model of higher education without universities spread across France's area of cultural influence during the first decades of the twentieth century, particularly in the Latinate European countries and their former colonies such as Portugal and Brazil, for example.",

- it should read:

\section{"The Cabanis reform}

The failure of the Fourcroy plan created an opportunity for the faculties to reemerge without central control by universities, culminating in the segmentation and isolation (or, as some said, elite-ization) of medical practice. Cabanis took advantage of his work as a teacher at the Ecole de Santé de Paris and his position as a representative in the Council of 
500, as well as a member of the Comite d'Instruction Publique, affirming the importance of the intellectual and political framework within this process. Under his active leadership, a set of proposals, documents, acts and standards were prepared, proposed and approved; with a certain historical detachment, I have proposed calling this set of developments the Cabanis reform (Almeida-Filho, 2017).

As an "archive" in the Foucauldian sense, the Cabanis reform unfolds in various texts, generally documents and reports which were submitted to and read before committees and legislative bodies: Observations sur les hôpitaux (1790); Travail sur l'éducation publique, trouvé dans les papiers de Mirabeau l'aîné (1791); Considérations genérales sur les révolutions de l'art de guérir (1795); Opinion sur le projet d'organisation des écoles primaires et en general sur l'instruction publique (1956a); Projet de résolution sur un mode provisoire de police médicale (1798c); Rapport fait au Conseil des Cinq-Cents sur le mode d'organisation des écoles de médecine (1798b); Quelques principes et quelques vues sur les secours publics (1956b). Some of these texts were gathered into thematic volumes, edited, and published as books: Rapports du physique et du moral de l'homme (1802); Coup d'oeil sur les revolutions et réforme de la médecine (1823).

As a general proposition, the Cabanis reform comprised five elements:

(1) an organizational model of higher education structured with faculties;

(2) medical education primarily professional in nature, more technical than scientific or cultural training;

(3) hospital-centered training based on interventionism;

(4) linear-progressing curricula geared toward disciplines;

(5) analytic pedagogical strategy separated by professions and restricted areas, tending toward specialization.

As I detailed elsewhere (Almeida-Filho, 2017), in Cabanis reform medical education would take place in independent schools, with the greatest possible autonomy from the central university body. Starting with the process of secularizing hospitals, new learning spaces were adapted to a clinical practice founded on systematic nosological knowledge. Instead of the master/apprentice relationship which was specific to the artisanal clinical training of that time, the Cabanis reform made instruction in hospitals compulsory, with the invention of the internship (internat des hopitaux) and later, medical residencies. At the end of the course, the institution would grant its graduates a university diploma, which was formally recognized and became a legal device allowing bearers to practice medicine and surgery as professionals. This was the basis for the hospital-centric and interventionist training that became dominant in medical education starting from the nineteenth century.

In general, Cabanis reform sought an organic link between philosophy, medicine, education, and politics, expressed in the "association of medical knowledge and analysis with a political project" (Saad, 2016, p.29), in an attempt to harmonize solutions which were at times contradictory or at least derived from conceptually different models. With Mirabeau, alongside the iconic rejection of Latin as a scientific lingua franca, the new goal was to surpass the university as a concept and as a coordinating body, creating a decentralized institutional structure based on faculties and isolated schools. Like Condorcet, the plan defended the recovery of the academies and scientific societies proscribed by the 1789 Revolution. Of the Thouret-Pinel-Cabanis plan, hospitals were to be reorganized 
into wards by morbidity classification, making them suitable instruction spaces to study and comparatively demonstrate cases. From the d'Azyr-Fourcroy plan, the therapeutic orientation of pharmaceutical chemistry was easily incorporated into a condensing of medicine, surgery, and pharmacy, accepting the field of comparative anatomy as the methodological axis of the basic sciences. From the epistemological agenda of the Idéologie, which Cabinis himself actively worked to construct, was added the elements of moral philosophy needed to mold the politically engaged citizen who also comprised the new profile of the doctor, which at that time was recommended to solidify (and perhaps overcome) the liberal agenda of the bourgeois revolution.

Conceptually, the reform's references included the naturalist philosophies and life sciences which were emerging in the first moments of modernity, adopting a semiotic theory of the clinic that connected physiology, pathology, and therapy. Scientific knowledge would be decomposed and recomposed according to Cartesian linear order, from the simplest to the most complex subject, in an exhaustive operation typical of the encyclopedia movement. The new curricular structure would be based on disciplinarity, with the knowledge broken down into its essential parts: the disciplines (or subjects), within the cognitive dimension, equivalent to the concept of catedra (chair) within the dimension of institutional organization. Analytical pedagogy guided by divisions into disciplines implied fragmentation, analysis, and subsequent reordering of blocks of content, modes of practice, and especially knowledge, which were memorized, stored, coded, and classified according to the prevailing scientific doctrines. The disciplines were to be precisely differentiated, and for reform of the medical education curriculum, grouped into natural history (basic sciences), materia medica (clinical and therapeutic sciences), and moral sciences. The main consequence this disciplinary model of curricular organization had on modes of health care was fragmentation of the practice (initially surgical, and later clinical) into medical specialties. In this sense, the Cabanis reform also promoted the tendency to divide and differentiate medical specialties ${ }^{11}$ which defined the mode of health care still hegemonic nowadays.

At the pedagogical dimension, the Cabanis reform meant a radical change in the use of rhetoric, in three aspects: first, it rejected manipulation of rhetoric in pedagogical strategies for training in the field of health, replacing the discourse of authority with greater emphasis on teaching based on experimentation. Second, the Cartesian method justified the systematic fragmentation of the training process as well as the object of the teachinglearning process. In fact, the resulting model of education was based on an apology to interdisciplinarity as a way of organizing and cataloging human knowledge into a rational and systematic structure, as advocated by the movement which became famous as Idéologie (Pouliquen, 2013; Saad, 2016). Third, a new rhetoric reordered the logic (in this case, the evidentiary logic) of the formulation of diagnostic reasoning based on signs and symptoms, within the process of constituting the clinical object (Ginzburg, 1989, p.177).

Rosen (1946, p.332), who is most representative among the Anglo-Saxon school of health historians, precisely defined what we call the Cabanis reform: "[the] program of reform and reconstruction in medical education which was initiated and carried out in France during the years between the Thermidorian reaction and the rise of Napoleon." In fact, many of the ideas, solutions, and actions that comprised the Cabanis reform first 
materialized in the reorganization of the Faculté de Médecine de Paris between 1794 and 1800, with Cabanis's active participation. Rosen (1946, p.337) also states that Cabanis's Coup d'oeil included "a program for reform of medical education" which, although it does not explicitly postulate the restoration of medical schools, featured ideas that "do reflect the basic philosophy of the instruction given the students at the Paris medical school." In this framework, the Coup d'oeil comprised a study of the history of health and of education in order to introduce a new pedagogy needed to reform medical education, which in turn was essential for the sustainability of the desired revolution in French medicine. To a certain extent this text can be considered a pilot plan for a specific section of a general educational reform (higher education in the health field), which in turn was part of a social reform agenda determined by the backlash of a political revolution, on the edge between Enlightenment and modernity.

The Cabanis reform in fact served as a model for the entire French higher education system, which at that time was structured as a network of isolated higher education institutions outside the university, such as the Polytechnic School and the École normale supérieure, which were intended to meet the requirements of the Industrial Revolution and demands for cadres for the state bureaucracy. To complete this picture, the only thing lacking was reorganization of the overall framework of the education system in order to replicate a regime that, although free from the old aristocratic order, in fact was not intended to prioritize those segments of society who were poor, oppressed, and exploited by the emerging mode of production. This step would be undertaken by the educational reform promoted by Napoleon Bonaparte, between 1802 and 1806.

Fourcroy returned to the scene at Napoleon's invitation, and from 1802 became the main political operator of Napoleonic educational reform as the General Director of Public Instruction, responsible for approving a general education reform law (Boudon, 2006). When Bonaparte was crowned emperor of France in 1804, his goal was to implement a strict regime to control the French educational system. To do so, he included the concept of the "imperial university" in his reform program as a body to simultaneously coordinate the education network of a given territory as well as a single teaching corps for the entire educational system. ${ }^{12}$

This institutional arrangement consolidated a linear curricular architecture throughout the entire subsystem of French higher education for professional career training through specific, exclusive, and specialized higher education, particularly in the field of health (Charle, Verger, 1996). Against the backdrop of political restoration, this process was quick and intense. In 1814-1815, the three medical faculties in Paris, Montpellier, and Strasbourg already had nearly 1,200 students, while the three schools of pharmacy had around 400 students registered (Boudon, 2007).

During the Third Republic alone, substantial changes in the French higher education system permitted the recovery (albeit partial) of the original idea of the university in France (Liard, 1894). Louis Liard (1846-1917), director of higher education as of 1884, was able to approve a series of decrees granting faculties autonomy to receive financial support, manage resources, and create chairs and courses (Weisz, 1983; Boudon, 2007). The Liard reform, which was approved by the French Parliament in July 1896, granted legal status to the 
faculty of the aggregated schools, which authorized the legal use of the term "university." With this case, the University of Paris-Sorbonne was immediately re-founded in November 1896, followed by the creation of another 15 universities in the interior of the country (Boudon, 2007). Despite its solid arguments and consistent formulation, the Liard reform can be considered a failure; to be approved, it was forced to include political concessions which prevented from achieving its objectives of reclaiming and renovating the concept of the university in France (Charle, Verger, 1996; Prost, 2009).

In the model of higher education which solidified during the Belle Époque, a century after the abolition of the universities by the French Revolution, the "empire of the faculties" remained strong, particularly regarding the so-called superior faculties (medicine and law) ${ }^{13}$ and the polytechnic schools which trained the professions considered imperial. Within this context, universities were merely nominal in existence, limited to political mediation and representing a group of faculties with their own political power and administrative and academic autonomy to the state. Despite its limitations, this model of higher education without universities spread across France's area of cultural influence during the first decades of the twentieth century, particularly in the Latinate European countries and their former colonies such as Portugal and Brazil, for example.",

- On pages 11-15, where it reads:

\section{"The Cabanis reform in Brazil}

In Brazil, as part of a secular strategy of domination, the Portuguese crown prohibited higher education during the colonial period. Only religious education was allowed in Jesuit schools; the first was founded by the priest Manoel da Nóbrega in Salvador, in 1553, as the Colégio do Salvador da Bahia. Other schools were then established in São Paulo, Porto Seguro, Rio de Janeiro, and Minas Gerais. Education was restricted to the scholastic model of the Ratio Studiorum; to complete one's studies, defend a thesis, and obtain a degree a scholar had to go to the University of Coimbra, in Portugal. The children of local nobility and upper-echelon officials pursuing secular higher education in law or medicine were also sent to other European universities such as those in Paris, Montpellier, and Edinburgh. With the expulsion of the Jesuits in 1759, the Pombal reform shattered the Jesuit dominance in education in the areas controlled by the Portuguese crown, but maintained the ban on opening higher education institutions in the colonies (Cunha, 2007, p.26-39).

The first institution of higher education in Brazil was founded in February 1808 by Dom João VI, the prince regent of Portugal who came to Bahia with his court as he fled the Napoleonic Wars, through a royal charter authorizing a school of surgery at the Royal Military Hospital of Salvador. Nine months later in that same year, a similar institution was established in Rio de Janeiro, where the Portuguese court was finally situated (Cunha, 2007). In inaugurating higher education in Brazil, the prince regent received the counsel of José Correia Picanço (1745-1823), a doctor to the royal family and the chief surgeon to the kingdom. Picanço was born in Pernambuco to a barber-surgeon father, from whom he learned his craft. At a very young age he entered the military; he then moved to Lisbon, 
where he studied at the São José Manoel Constantius Hospital School of Surgery, considered the founder of academic surgery in Portugal. According to his biographers (Mello, 1895; Gomes, 1951; Vasconcellos, 1955), in 1767 Picanço traveled to Paris to complete his studies, taking practical examinations to receive a diploma of officier de santé in 1768 and confirming his credentials as a surgeon. He returned to France in 1772 to obtain a doctorate in medicine from the University of Paris, in order to assume the chair of anatomy, surgical operations, and obstetrics at the University of Coimbra's School of Medicine.

The biographical information available about Correia Picanço has been repeatedly plagiarized in various narratives about the official history of medical education in Brazil, replicating errors, contradictions, and inconsistencies. ${ }^{13}$ Notable among this lack of agreement is the exact location of his surgical studies, which took place in Paris, Montpellier, or even Padua: both Gomes (1951, p.160) and Vasconcellos (1955, p.239) mention these three places but do not indicate sources (Gomes: "returning to Lisbon, tradition states, after attending the schools in Montpellier and Padua;" Vasconcellos: "References state that Correa Picanço attended the schools of medicine in Montpellier and Padua"). Furthermore, the concept of officier de santé was only established in 1793 by the Convention, and its respective certification was dependent on the écoles de santé, which were established in 1794 (Crosland, 2004, p.236). Consequently it was impossible for Picanço to receive a "diploma of Officier de Santé" in 1768, as Gomes (1951, p.160) states. Thirdly, officier de santé was not an "honorary title ... a new step in his ascendant medical career," according to Vasconcellos (1955, p.239). As we have seen above, this category denoted a lower class of health professionals with shorter training and limited competence which acquired a minimally formal status during a fleeting moment of the French Revolution (1794-1802), suffering discrimination and repercussions from physicians and surgeons who were unified in the category of medecins (Rey, 1993). Therefore Correia Picanço cannot have been an officier de santé, raising a question that at the very least is intriguing: where did his biographer obtain this false information, and why did he present this scorned category as if it were a respected title? ${ }^{14}$

There is no doubt that Correia Picanço, his colleagues, and his disciples were very familiar with Cabanis's clinical work. One of the first books published by the Brazilian Royal Press, founded by Dom João VI in Rio de Janeiro, was Cabanis's compendium on diagnosis, translated by Dr. Picanço himself, with the title Do grau de certeza da madicina [On the degree of certainty of medicine] (Guerra, 1987). A rare collection of clinical records by Cabanis, Observations sur les affections catarrhales, was published in 1816 in Bahia, in a translation by José Lino dos Santos Coutinho (Guerra, 1987).

The Pombaline model of the secular university, which had recently emerged from Scholasticism in the aftermath of the Inquisition, experimented with new functions for training staff for nascent industry and for the armed forces, anachronistically shaping itself to the Brazilian post-colonial ideological scene (Cunha, 2007). The institutions created in Salvador and Rio de Janeiro were not schools of medicine but rather schools of anatomy and surgery, as noted by Lycurgo Santos-Filho (1980, p.77), the dean of historians of medicine in Brazil. The course lasted four years; after students took their examinations (and swore an oath on the Holy Gospels), they received a certificate of competence, with doctors of medicine continuing to seek their advanced training in Europe, especially in Coimbra. The 
first reforms in both schools, which came to be called medical-surgical academies, took place between 1812 and 1815 . The reforms expanded the disciplines from five to fourteen, and required department chairs to be present in the classroom. After Independence in 1826, Emperor Dom Pedro I granted relative autonomy to these academies, granting them the right to issue diplomas (Machado et al., 1978).

In 1829 the Society of Medicine and Surgery of Rio de Janeiro was created to promote and defend medical and surgical sciences (Ferreira, Maio, Azevedo, 1997). Its first official act was set up a temporary commission to draft a law establishing medical colleges in Brazil. According to Roberto Machado et al. (1978, p.185):

This creation clearly shows its French inspiration. We can see this influence not only in the presence of French doctors among its founders (the doctors Faivre and Sigaud, who had been secretary of the Royal Society of Medicine of Marseille) and in the training of several of its members (the idea of this creation began with Dr. Meirelles, pursuing his doctorate in Paris), but above all (and because) the plan for social medicine was entirely based on what had been done in France by the medical societies.

For almost two years, the society carried out studies, held public hearings, and discussed the recommendations of the Temporary Commission. A proposal was submitted which simply replicated the statutes of the Paris School of Medicine and adapted its education programs to local conditions, extending the training to six years. The bill was approved by Parliament in 1832, without amendments (Machado et al., 1978).

The two medical-surgical academies of Bahia and Rio de Janeiro were then transformed into medical schools, strictly following the guidelines of the Cabanis reform. The law stipulated that no person without a degree conferred or approved by the schools could heal, perform surgery, act as a midwife, or run a pharmacy. Until 1850, professional activity was supervised and controlled by the schools themselves, which held examinations and conferred degrees and certificates, together with the municipal councils, which registered titles and granted licenses to lawfully work in these professions (Machado et al., 1978, p.178-179). In 1854, a congregation of department chairs (Congregação de Lentes) was defined in order to act as the board of the schools and to elect a director.

In 1879, based on a proposal by Vincent Figueira of Savoy, ${ }^{15}$ the Leôncio de Carvalho reform was intended to profoundly alter the structure of Brazilian medical education. Inspired by the model of the German universities (and contrary to the rhetorical education in the French colleges), this reform advocated practical teaching, with the creation of laboratories for medical physics, organic chemistry, physiology, and pharmacology, with less importance given to magistral classes. In order to provide better training for the students, the course was extended to six years, public interrogation of candidates was abolished, and practical tests and examinations were made obligatory to obtain academic degrees, including diplomas for pharmacists and dentists. Only after this reform were women permitted to enter medical courses, with the first female physician, Rita Lobato Velho Lopes from Rio Grande do Sul, graduating in 1887 from the school in Bahia (Lobo, 1971).

Throughout the nineteenth century, the French influence on Brazilian medical teaching was profound and comprehensive. The educational model which was adopted continued 
to be ritualized and rhetorical, strongly marked by French post-restoration scholarship. ${ }^{16}$ In terms of the actual teaching, the entire body of material (books, methods, regulations, programs, readings) was all imported from France (Machado et al., 1978, p.180). Focusing on the situation in Rio de Janeiro, where the work of the Corvisart, Laennec, and Bichat was fundamental to medical education, Pedro Nava (2003, p.63) highlights the role of José Maria Bomtempo and Joaquim da Rocha Mazarem, doctors to the Portuguese court "who opened the doors of our medicine to the influx of the French masters which would be so beneficial and lasting."

In their study of the collection of the Bahia Medical School which investigated the philosophical schools which were influential during the imperial period, Lima Júnior and Berbert de Castro (2006) found a strong if delayed influence of the Idéologie and its icons (Tracy, Condillac, Maine de Biran, and especially Cabanis), in addition to early references to Comtean positivism. Particularly in relation to Cabanis, all his physiological and clinical writings were included in the collections of the medical schools in Bahia and Rio de Janeiro, as well as the private libraries of several local intellectuals who had trained in France (Lima Júnior, Castro, 2006). Elements of Cabanis's work were repeated (and often plagiarized) in the titles and contents of many inaugural theses ${ }^{17}$ at the Bahia Medical School. A very apt example is the thesis by Antonio Januario de Farias (1845) entitled A certeza em medicina [Certainty in medicine], with an epigraph and profuse citations mentioning the originals by Cabanis, Du degré of certitude de la médecine (1798a), Publications du physique et du moral de l'homme (1802), and even Coup d'oeil sur les révolutions et retrofit de la médecine (1823).

For more than a century no attempt to organize universities had been successful in Brazil, even though some proposals were been adopted at different levels of the legislature. I shall highlight the most important examples, following the historical review by Fávero (2010). In 1823, the Public Instruction Commission of the Constituent Assembly, led by José Bonifácio de Andrada e Silva, submitted a public education plan which maintained the medical schools in Bahia and Rio de Janeiro but called for two universities in São Paulo and Olinda governed by the statutes of the University of Coimbra. This proposal was approved with amendments, but Dom Pedro I dissolved the constituent Parliament and nullified its deliberations. Senator Manuel Castro e Silva presented a similar proposal in 1842, but the large volume of criticism and objections during two years of debate in Parliament culminated in a demonstration against the Bahia Medical School, and the proposal was shelved in 1845. In 1882, Baron Homem de Melo again proposed the creation of universities in major cities across the country, but the college model prevailed. ${ }^{18}$

During the nineteenth century, with the opening of colleges of law in São Paulo and Recife as well as mining, agriculture, and polytechnic schools in Rio de Janeiro, Minas Gerais, and Bahia, an educational model was established in Brazil that eliminated the institutional figure of the university (Fávero, 2010). In this way the "empire of the colleges" prevailed, with direct-entry medical courses, closed curricula, department chairs and adjunct professor-type arrangements, master classes, and diplomas acting to license the profession, in accordance with the Cabanis reform. After the Proclamation of the Brazilian Republic in 1889, the strong presence of positivism in the organization of the nation expanded French cultural influence, establishing the Bonapartist model of education 
based on the system of the primary school, lycée, normal school, polytechnic schools, and colleges (Ferreira et al., 1977).

At the turn of the twentieth century, with the creation of the Porto Alegre School of Medicine and Pharmacy, in Brazil there were three schools of medicine, two schools of law, two polytechnic schools, and no universities. This situation continued into the first three decades of the twentieth century. The first initiative to unify the schools in the federal capital and create the University of Rio de Janeiro, shortly before the hundredth anniversary of independence in 1922, only had a symbolic effect (Fávero, 2010, p.30-31).

The first Brazilian university was in fact the University of São Paulo, instituted in 1934 by a state law through the incorporation of existing institutions: the School of Medicine, School of Law, Polytechnic School, Luiz de Queiroz Superior School of Agriculture, and the Institute of Education, as well as the establishment of a School of Sciences, Literature, and Arts (Cunha, 2007, p.241). For decades this institution was the main center of scientific and academic training in the country, and was designed from a political-institutional plan replicating the model of the University of Paris-Sorbonne. Its establishment, organization, and consolidation between 1934 and 1945 received support from a French mission organized by Georges Dumas, a professor of sociology at the Sorbonne, and Teodoro Ramos, professor at the Polytechnic School (Paula, 2002). ${ }^{19}$

The federal universities for the most part were established after the Vargas dictatorship, following the same process of agglomerating existing traditional colleges, promoting institutional isolation and symbolic and political autonomy (Cunha, 2007). The exception was the University of Brasilia (UnB), which was conceived by Anísio Teixeira and Darcy Ribeiro as a research university with a curricular structure inspired by the American model, an institutional experiment which was harshly repressed by the military dictatorship (Salmeron, 2008). There was no separate medical school at UnB, but rather a Center for Health Sciences intended for integrated training of all health professions. Political repression caused regression that ended with the fragmentation of the UnB training centers, which two decades later resulted in the return to the old format of the medical school in a university which was almost nominal, according to the model resulting from the Liard reform in 1896.",

- it should read:

\section{"The Cabanis reform in Brazil}

In Brazil, as part of a centuries-old strategy of domination, the Portuguese crown prohibited higher education during the colonial period. Only religious education was allowed in Jesuit schools; the first was founded by the priest Manoel da Nóbrega in Salvador, in 1553, as the Colégio do Salvador da Bahia. Other schools were then established in São Paulo, Porto Seguro, Rio de Janeiro, and Minas Gerais. Education was restricted to the post-scholastic model of the Ratio Studiorum; to complete one's studies, defend a thesis, and obtain a degree a scholar had to go to the University of Coimbra, in Portugal. The children of local nobility and upper-echelon officials pursuing secular higher education in law or medicine were also sent to other European universities such as those in Paris, Montpellier, and Edinburgh. With the expulsion of the Jesuits in 1759, the Pombal reform 
shattered the Jesuit dominance in education in the areas controlled by the Portuguese crown, but maintained the ban on opening higher education institutions in the colonies (Cunha, 2007, p.26-39).

The first institution of higher education in Brazil was founded in February 1808 by Dom João VI, the prince regent of Portugal who came to Bahia as he and his court fled the Napoleonic Wars, through a royal charter authorizing a school of surgery at the Royal Military Hospital of Salvador. Nine months later in that same year, a similar institution was established in Rio de Janeiro, where the Portuguese court was finally situated (Cunha, 2007). In inaugurating higher education in Brazil, the prince regent received the counsel of José Correia Picanço (1745-1823), a doctor to the royal family and the chief surgeon to the kingdom. Picanço was born in Pernambuco to a barber-surgeon father, from whom he learned his craft. At a very young age he entered the military; he then moved to Lisbon, where he studied at the São José Hospital School of Surgery under the mentorship of Manoel Constâncio, who is recognized as the founder of academic surgery in Portugal. According to his biographers (Mello, 1895; Gomes, 1951; Vasconcellos, 1955), in 1767 Picanço traveled to Paris to complete his studies, taking practical examinations to receive a diploma of officier de santé in 1768 and confirming his credentials as a surgeon. He returned to France in 1772 to obtain a doctorate in medicine from the University of Paris, in order to assume the chair of anatomy, surgical operations, and obstetrics at the University of Coimbra's Faculty of Medicine.

The biographical information available about Correia Picanço has been repeatedly plagiarized in various narratives about the official history of medical education in Brazil, replicating errors, contradictions, and inconsistencies. ${ }^{14}$ Notable in this registry of misinformation is the exact location of Picanço's surgical studies, which supposedly took place in Paris, Montpellier, or even Padua: both Gomes (1951, p.160) and Vasconcellos (1955, p.239) mention these three places but do not indicate sources (Gomes: "Returning to Lisbon, tradition states, after attending the schools in Montpellier and Padua;" Vasconcellos: "References state that Correa Picanço attended the schools of medicine in Montpellier and Padua"). Furthermore, the concept of officier de santé was only established in 1793 by the Convention, and its respective certification was dependent on the écoles de santé, which were established in 1794 (Crosland, 2004, p.236). Consequently, it was impossible for Picanço to receive a "diploma of Officier de Santé" in 1768, as Gomes (1951, p.160) states. Thirdly, officier de santé was not an "honorary title ... a new step in his ascendant medical career," according to Vasconcellos (1955, p.239). As we have seen above, this category denoted a lower class of health professionals with shorter training and limited competence which acquired a minimally formal status during a fleeting moment of the French Revolution (1794-1802). Actually, officiers de santé suffered discrimination and prejudice from physicians and surgeons who were unified in the category of médecins (Rey, 1993). Therefore, Correia Picanço cannot have been an officier de santé, raising a question that at the very least is intriguing: where did his biographer obtain this false information, and why did he present this scorned category as if it were a respected title? ${ }^{15}$

There is no doubt that Correia Picanço, his colleagues, and his disciples were very familiar with Cabanis's clinical work. One of the first books published by the Brazilian 
Royal Press, founded by Dom João VI in Rio de Janeiro, was Cabanis's compendium on diagnosis, translated by Dr. Picanço himself, with the title Do gráo de certeza da medicina (On the degree of certainty of medicine) (Guerra, 1987). A rare collection of clinical records by Cabanis, Observations sur les affections catarrhales, was published in 1816 in Bahia, in a translation by José Lino dos Santos Coutinho (Guerra, 1987).

The Pombaline model of the secular university, which had recently emerged from Scholasticism in the aftermath of the Inquisition, experimented with new functions for training staff for nascent industry and for the armed forces, anachronistically shaping itself to the Brazilian post-colonial ideological scene (Cunha, 2007). The institutions created in Salvador and Rio de Janeiro were not schools of medicine but rather schools of anatomy and surgery, as noted by Lycurgo Santos-Filho (1980, p.77), the forefather of historians of medicine in Brazil. The course lasted four years; after students took their examinations (and swore an oath on the Holy Gospels), they received a certificate of competence, but those continuing to seek their advanced training as doctors of medicine should pursue their degrees in Europe, especially in Coimbra (Santos-Filho, 1980). The first reforms in both schools, which came to be called medical-surgical academies, took place between 1812 and 1815. The reforms expanded the disciplines from five to fourteen, and required students to be present in the classroom. After Independence, in 1826, Emperor Dom Pedro I granted relative autonomy to these academies, granting them the right to issue diplomas (Machado et al., 1978).

In 1829 the Society of Medicine and Surgery of Rio de Janeiro was created to promote and defend medical and surgical sciences (Ferreira, Maio, Azevedo, 1997). Its first official act was set up a temporary commission to draft a law establishing medical faculties in Brazil. According to Roberto Machado et al. (1978, p.185):

This creation clearly shows its French inspiration. We can see this influence not only in the presence of French doctors among its founders (the doctors Faivre and Sigaud, who had been secretary of the Royal Society of Medicine of Marseille) and in the training of several of its members (the idea of this creation began with Dr. Meirelles, pursuing his doctorate in Paris), but above all (and because) the plan for social medicine was entirely based on what had been done in France by the medical societies.

For almost two years, the society carried out studies, held public hearings, and discussed the recommendations of the Temporary Commission. A proposal was submitted which simply replicated the statutes of the Paris School of Medicine and adapted its education programs to local conditions, extending the training to six years. The bill was approved by Parliament in 1832, without amendments (Machado et al., 1978).

The two medical-surgical academies of Bahia and Rio de Janeiro were then transformed into medical schools, strictly following the guidelines of the Cabanis reform. The law stipulated that no person without a degree conferred or approved by the schools could heal, perform surgery, act as a midwife, or run a pharmacy. Until 1850, professional activity was supervised and controlled by the schools themselves, which held examinations and conferred degrees and certificates, together with the municipal councils, which registered titles and granted licenses to lawfully work in these professions (Machado et al., 1978, p.178-179). In 1854, a congregation of chairpersons (Congregação de Lentes) was defined in order to act as the board of the schools and to elect a director. 
In 1879, based on a proposal by Vicente Figueira de Saboia, ${ }^{16}$ the Leôncio de Carvalho reform was intended to profoundly alter the structure of Brazilian medical education. Inspired by the model of the German universities (and contrary to the rhetorical education in the French faculties), this reform advocated practical teaching, with the creation of laboratories for medical physics, organic chemistry, physiology, and pharmacology, with less importance given to magistral classes. In order to provide better training for the students, the course was extended to six years, public interrogation of candidates was abolished, and practical tests and examinations were made obligatory to obtain academic degrees, including diplomas for pharmacists and dentists. Only after this reform were women permitted to enter medical courses, with the first female physician, Rita Lobato Velho Lopes from Rio Grande do Sul, graduating in 1887 from the medical school in Bahia (Lobo, 1971).

Throughout the nineteenth century, the French influence on Brazilian medical teaching was profound and comprehensive. The educational model which was adopted continued to be ritualized and rhetorical, strongly marked by French post-restoration scholarship..$^{17}$ In terms of the actual teaching, the entire body of material (books, methods, regulations, programs, readings) was all imported from France (Machado et al., 1978, p.180). Focusing on the situation in Rio de Janeiro, where the work of the Corvisart, Laennec, and Bichat was fundamental to medical education, Pedro Nava (2003, p.63) highlights the role of José Maria Bomtempo and Joaquim da Rocha Mazarem, doctors to the Portuguese court "who opened the doors of our medicine to the influx of the French masters which would be so beneficial and lasting."

In their study of the collection of the Faculdade de Medicina da Bahia which investigated the philosophical schools influential during the imperial period, Lima Júnior and Berbert de Castro (2006) found a strong if delayed influence of the Idéologie and its icons (Tracy, Condillac, Maine de Biran, and especially Cabanis), in addition to early references to Comtean positivism. Particularly in relation to Cabanis, all his physiological and clinical writings were included in the collections of the medical schools in Bahia and Rio de Janeiro, as well as the private libraries of several local intellectuals who had trained in France (Lima Júnior, Castro, 2006). Elements of Cabanis's work were repeated (and often plagiarized) in the titles and contents of many inaugural theses ${ }^{18}$ at the Faculdade de Medicina da Bahia. A very apt example is the thesis by Antonio Januario de Farias (1845) entitled A certeza em medicina (Certainty in medicine), with an epigraph and profuse citations mentioning the originals by Cabanis, Du degré of certitude de la médecine (1798a), Rapports du physique et du moral de l'homme (1802), and even Coup d'oeil sur les révolutions et réformes de la médecine (1823).

For more than a century no attempt to organize universities had been successful in Brazil, even though some proposals were adopted at different levels of the legislature. I shall highlight the most important examples, following the historical review by Fávero (2010, p.23-26). In 1823, the Public Instruction Commission of the Constituent Assembly, led by José Bonifácio de Andrada e Silva, submitted a public education plan which maintained the medical schools in Bahia and Rio de Janeiro but called for two universities in São Paulo and Olinda governed by the statutes of the University of Coimbra. This 
proposal was approved with amendments, but Dom Pedro I dissolved the constituent Parliament and nullified its deliberations. Senator Manuel Castro e Silva presented a similar proposal in 1842, but the large volume of criticism and objections during two years of debate in Parliament culminated in a protest led by the Faculdade de Medicina da Bahia, and the proposal was shelved in 1845. In 1882, Baron Homem de Melo again proposed the creation of universities in major cities across the country, but the faculty model prevailed. ${ }^{19}$

During the nineteenth century, with the opening of faculties of law in São Paulo and Recife as well as mining, agriculture, and polytechnic schools in Rio de Janeiro, Minas Gerais, and Bahia, an educational model was established in Brazil that eliminated the institutional figure of the university (Fávero, 2010). In this way the "empire of the faculties" prevailed, with direct-entry medical courses, closed curricula, chairmen and adjunct professorships, master classes, and diplomas acting to license professions, in accordance with Cabanis reform. After the Proclamation of the Brazilian Republic in 1889 , the strong presence of positivism in the organization of the nation expanded French cultural influence, consolidating the Bonapartist model of education based on the system of the primary school, lycée, normal school, polytechnic schools, and faculties (Ferreira et al., 1977).

At the turn of the twentieth century, with the creation of the Porto Alegre Faculdade Livre de Medicina e Farmácia, in Brazil there were three faculties of medicine, two faculties of law, two polytechnic schools, and no universities. This situation continued into the first three decades of the twentieth century. The first initiative to unify the schools in the federal capital and create the University of Rio de Janeiro, shortly before the hundredth anniversary of independence in 1922, only had a symbolic effect (Fávero, 2010, p.30-31).

The first Brazilian university was in fact the University of São Paulo, instituted in 1934 by a state law through the incorporation of existing institutions: the Faculty of Medicine, Faculty of Law, Polytechnic School, Luiz de Queiroz Superior School of Agriculture, and the Institute of Education, as well as the establishment of a Faculdade de Ciências, Letras e Artes (Cunha, 2007, p.241). For decades, this institution was the main center of scientific and academic training in the country, and was designed from a political-institutional plan which replicated the model of the University of Paris-Sorbonne. Its establishment, organization, and consolidation between 1934 and 1945 received support from a French mission organized by Georges Dumas, a professor of sociology at the Sorbonne, and Teodoro Ramos, professor at the Polytechnic School (Paula, 2002). ${ }^{20}$

The federal universities were in majority established after the Vargas dictatorship, following the same process of aggregating existing traditional faculties, promoting institutional isolation and symbolic and political autonomy (Cunha, 2007). The exception was the University of Brasília (UnB), which was conceived by Anísio Teixeira and Darcy Ribeiro as a research university with a curricular structure inspired by the American model, an institutional experiment which was harshly repressed by the military dictatorship (Salmeron, 2008). There was no medical school at UnB, but rather a Center for Health Sciences intended for integrated training of all health professions. Political repression caused a regression that ended with the fragmentation of the UnB training centers, which two decades later resulted in the return 
to the old format of the medical faculty separate in a university which was almost nominal, according to the model resulting from the Liard reform in 1896.".

- On pages $15-18$, where it reads:

\section{“Final considerations}

In a neo-Foucauldian interpretation, higher education reform in the French postrevolutionary process can be considered a political response to the crisis of the university in Enlightenment Europe. During a process of accommodation that lasted nearly a century, this reform reduced the thousand-year-old institution of the university to a mere connection between symbolically valued and politically empowered independent entities: the colleges. With a disproportionate presence in proposals for educational reform, the restructuring of medical teaching dominated the scene and culminated in the Cabanis reform. Given the huge political capital accumulated by doctor/politician/ managers during the fall of the Ancien Régime and the role of doctors in the perception of the emerging bourgeois society, the Cabanis reform was inspiring and perhaps a catalyst for general reform in the French educational system.

The fact that a topical transformation evolved into a widespread rupture and was embraced even by movements that opposed it in principle was certainly due to what Foucault (2004) would later call biopolitics, in one of its most powerful regional modalities: medical power (Clavreuil, 1975). In other words, again the centrality of care practices in the constitution of modern societies is highlighted, to the extent that a sectoral reform in medical education resulted in profound changes in higher education, causing extensive restructuring of the system of education in general. ${ }^{20}$

Assessment of the relevance and validity of the hypothesis that medical education in Brazilian universities structurally retained the guiding concepts of the Cabanis reform implies verifying the concrete and effective presence of the following structural elements (in whole or in part) in the establishments, programs, or training courses on health in Brazil: (a) professional-oriented university; (b) structured into colleges; (c) interventionist training; (d) oriented around disciplines; (e) linear progression scheme; (f) analytical pedagogy; (g) separated by professions; (h) tending toward specialization.

With regard to the first three points, the initial approach to the historical process of establishing the model of higher education which predominates in Brazil and which was presented in this work confirms the presence of these organic elements as the direct result of the Cabanis reform, reflected in the institutional mimicry observed during the phases of establishing of the national schools of medicine during the Regency and the Second Empire (Nava, 2003). Furthermore, particularly in the Bahia Medical School, the direct effects of Cabanis's thought can be seen as philosophical inspiration and clinical reference, alongside his indirect influence in the important intellectual leadership of the Idéologie movement and subsequent inspiration of positivism.

This point no longer concerns confirming whether the reform of higher education proposed by Cabanis really was truly the embryo of medical teaching in Brazil. A simple panoramic examination shows that this hypothesis is both robust and valid, consistent 
with the structure of the current training scheme. In fact, this finding was already evidenced in the relevant section, and its demonstration was trivial. The question then is not whether the roots of higher education in health and medical practice in Brazil replicate the French model of training, but instead to what extent (in what forms, how etc.) they result from the Cabanis reform, mediated by the influence of positivism during the First Republic. Nevertheless, for even more in-depth assessment of this political-institutional dimension, comparative studies of the organizational structure and regulatory framework of higher education institutions are recommended in order to generate typologies which can establish the different formats directly or indirectly created by the Cabanis reform in different cultural, geopolitical, and historical contexts.

As for the remaining items (curricular structure, teaching programs, pedagogical strategies, professional separation, specialization), we can expect greater variation in the direct effects of the Cabanis reform, which can be accessed through documentary and ethnographic approaches within the sphere of everyday practices of teaching and learning. This will involve assessing how (in what formats, modalities, types, operations, processes etc.) the model of health education (and, by extension, higher education in general) in Brazil remains Cabanist and Bonapartist from a structural point of view. The scope would include research (which would doubtless be rich and relevant) to verify cases, variants, and specificities. Of course, in the different cases of institutionalization of higher education and medical training which were influenced by French culture, traditions, schools and generations of social studies of educational practices produced information and accumulated knowledge, even with a lesser degree of systematization which awaits methodical compilation, systematic organization, and competent analysis.

In conclusion, in twentieth-century Brazil, despite strong "Humboldtian" traits in research and post-graduate studies which appear in a reduced scenario of higher education institutions, and even though "Flexnerian" influences have disappeared, especially in specialized clinical training, and despite the presence of isolated experiments targeting "Freirean" pedagogical innovation, we continue on a "Cabanist" path from a structural point of view, with a health education system founded on colleges, diplomas, and hospitals and a model of teaching and learning based on disciplines, classes, and content. We should also consider the hypothesis that the Brazilian university, in its near-century of formal existence, remains fixed in the "Bonapartist" restoration, considering its conservative authoritarianism and aversion to the new cultivated and barely hidden in its latent and denied roots, which are only seen when the institution resists and refuses creative renovation.

Careful analysis of so many anachronisms, inertias, latencies, and appropriations which are more evident in the sub-space of medical teaching will without a doubt provide better understanding (even if this is limited and partial) of the profound contradictions of the Brazilian university. Thus, more important than origins and roots (past, old, and certainly overcome), it will be appropriate to verify the remainders, the signs, the indications and the revelatory effects, not of occurrences that were relevant in a distant past, but of concrete, working, active, and currently relevant elements. All this inside a regime of medical education that is part of an institution which in turn is organic within today's unfair and unequal economic, social, and political context. The in-depth investigation of this regime, 
its roots, and its correlations will provide a coup d'oeil glimpse of the connections between this elitist and exclusionary university and the political and institutional processes of reproducing inequalities, privileges, and social inequalities, which are only possible and sustainable with the passive complicity and active participation of the current system of higher education in our country.",

- it should read:

\section{“Final considerations}

In a neo-Foucauldian interpretation, the higher education reform in French postrevolutionary process can be considered a political response to the crisis of the university in Enlightenment Europe. During a process of accommodation that lasted nearly a century, this reform reduced the thousand-year-old institution of the university to a mere connection between symbolically valued and politically empowered independent entities: the faculties. With a disproportionate presence in proposals for educational reform, the restructuring of medical teaching dominated the scene and culminated in the Cabanis reform. Given the huge political capital accumulated by doctor/politician/managers during the fall of the Ancien Régime and the role of doctors in the imaginary of the emerging bourgeois society, the Cabanis reform was inspiring and perhaps a catalyst for general reform in the French educational system.

The fact that a topical transformation evolved into a widespread rupture and was embraced even by movements that opposed it in principle was certainly due to what Foucault (2004) would later call biopolitics, in one of its most powerful regional modalities: medical power (Clavreuil, 1975). In other words, again the centrality of healthcare practices in the constitution of modern societies is highlighted, to the extent that a sectoral reform in medical education resulted in profound changes in higher education, causing extensive restructuring of the system of education in general. ${ }^{21}$

Assessment of the relevance and validity of the hypothesis that medical education in Brazilian universities structurally retained the guiding concepts of Cabanis reform implies verifying the concrete and effective presence of the following structural elements (in whole or in part) in the establishments, programs, or training courses on health in Brazil: (a) professional-oriented university; (b) structured into faculties; (c) interventionist training; (d) oriented toward disciplinarity; (e) linear progression scheme; (f) analytical pedagogy; (g) separated by professions; (h) tending toward specialization.

With regard to the first three points, the initial approach to the historical process of establishing the model of higher education which predominates in Brazil today, as presented in this paper, confirms the presence of these organic elements as a direct result of Cabanis reform, reflected in the institutional mimicry observed during the consolidation phases of the national faculties of medicine during the Regency and the Second Empire (Nava, 2003). Furthermore, particularly in the Bahia medical school, the direct effects of Cabanis's thought can be seen as philosophical inspiration and clinical reference, alongside his indirect influence as an important intellectual leader of the Idéologie movement and, subsequently, as inspiration for the positivism. 
At this point, we are no longer concerned with confirming whether the reform of higher education proposed by Cabanis was truly the embryo of medical teaching in Brazil. A simple panoramic examination shows that this hypothesis is both robust and valid, consistent with the structure of the current training scheme. In fact, this finding was already evidenced in the corresponding section above, and its demonstration is therefore trivial. The question then is not whether the roots of higher education in health and medical practice in Brazil replicate the French model of training or not, but instead to what extent (in what forms, how etc.) they result from the Cabanis reform, mediated by the influence of positivism during the First Republic. Nevertheless, for even more in-depth assessment of this political-institutional dimension, comparative studies of the organizational structure and regulatory framework of higher education institutions are recommended in order to generate typologies which can establish the different formats directly or indirectly created by the Cabanis reform in different cultural, geopolitical, and historical contexts.

As for the remaining items (curricular structure, teaching programs, pedagogical strategies, professional separation, specialization), we would expect greater variation in the direct effects of Cabanis reform, which can be accessed through documentary and ethnographic approaches within the sphere of everyday practices of teaching and learning. This will involve assessing how (in what formats, modalities, types, operations, processes etc.) the model of health education (and, by extension, higher education in general) in Brazil remains Cabanist and Bonapartist from a structural point of view. The research scope (which would doubtless be rich and relevant) include studies to verify cases, variants, and specificities. Of course, in the different cases of institutionalization of higher education and medical training which were influenced by French culture, traditions, schools and generations of social studies of educational practices produced valid information and accumulated knowledge, even with a lesser degree of systematization, which awaits methodical compilation, systematic organization, and competent analysis.

In conclusion, in twentieth-century Brazil, despite strong "Humboldtian" traits in research and post-graduate studies which appear in a small number of higher education institutions, and even though fleeting "Flexnerian" flashes seeing particularly in specialized clinical training, and despite the presence of isolated experiments targeting "Freirean" pedagogical innovation, we continue on a "Cabanist" path. From a structural point of view, our health education system is still founded on faculties, diplomas, and hospitals, with a model of teaching-learning based on disciplines, classes, and contents. Beyond that, we should also consider the hypothesis that the Brazilian university, in its nearcentury of formal existence, remains fixed in the "Bonapartist" restoration, considering its conservative authoritarianism and aversion to the new cultivated and barely hidden in its latent and denied roots, which are only seen when the institution resists and refuses creative renovation.

Careful analysis of so many anachronisms, inertias, latencies, and appropriations which are more evident in the sub-space of medical teaching will without a doubt provide better understanding (even if this is limited and partial) of the profound contradictions of the Brazilian university. Thus, more important than origins and roots (past, old, and certainly overcome), it will be appropriate to verify the remainders, the signs, the indications and 
the revelatory effects, not of occurrences that belonged to a distant past, but of concrete, working, active elements, which are currently relevant. All this inside a regime of medical education that is part of an institution which in turn is organic within today's unfair and unequal economic, social, and political context. The in-depth investigation of this regime, its roots, and its correlations will provide a coup d'oeil, a glimpse of the connections between this elitist and exclusionary university and the political and institutional processes of reproducing inequalities, privileges, and social inequalities, which are only possible and sustainable with the passive complicity and active participation of the current system of higher education in our country.".

- On pages $17-18$, where it reads:

\section{“ACKNOWLEDGMENTS}

The author wishes to acknowledge the invaluable contribution by Jacques Salah, professor emeritus of French literature in the department of literature at the Federal University of Bahia and ex-consul of France in Bahia, for revising the translation of the original quotes in French, as well as his generous critical reading of early versions of this text. Thanks also to Luiz Antonio de Castro Santos, who at the time was senior visiting professor at the Federal University of Bahia, for his criticism of early versions of this manuscript and valuable suggestions of historical references.

\section{NOTES}

${ }^{1}$ Cabanis is mentioned 43 times in Naissance de la Clinique (Foucault, 1963), one time for every ten pages; in Folie et déraison (Foucault, 1961), he appears 21 times, on 17 of the book's 550 pages.

${ }^{2}$ Analysis of the Avicennian rupture is beyond the limits of my competence; moreover, except as symbology and discursiveness, little of this rupture is retained in the contemporary context of healthcare.

${ }^{3}$ For this and other citations of texts from non-English languages, a free translation has been provided.

${ }^{4}$ To the extent that Foucault, by promoting dissent within his own project for a cultural history of western thought (which he called a "genealogical approach") disowned himself to a certain extent, I propose to designate any movement toward recovering or eventually renewing the archaeological perspective as a valid, relevant methodological tool for a critical history of healthcare modes as neo-Foucauldian.

${ }^{5}$ As Foucault himself states (1994, p.508): “L'hôpital entant qu'instrument thérapeutique est en effet un concept relativement moderne, puis qu'il date de la fin du XVIIIe siècle. C'est autour de 1760 qu'est apparue l'idée que l'hôpital pouvait et devait être un instrument destiné à guérir le malade. Cela se produit au travers d'une nouvelle pratique: la visite et l'observation systématique et comparée des hôpitaux."

${ }^{6}$ In the original: "L'anatomie seule n'est pour ainsi dire que le squelette de la science; c'est la physiologie qui lui donne du mouvement: l'une est l'étude de la vie, l'autre n'est que l'étude de la mort."

${ }^{7}$ Unfortunately, d'Azyr did not survive the Reign of Terror to see the advance of reforms in French medicine. He was indicted by the feared Comite de salut public for publicly protesting the expulsion of the spirit of revolution in the new Republican Constitution, which was approved by an assembly that excluded the Girondins. He was pursued by popular militias; malnourished and delirious, he died under mysterious circumstances in 1793 (Schmitt, 2009).

${ }^{8}$ In the original: "Un praticien renommé qui doit être indemnisé."

${ }^{9}$ In the original: “Une bonne conduite, des moeurs pures, l'amour de la République et la haine des tyrans; une education assez soignée; pour qu'on soit assuré que les élèves possèdent les premiers élémens des sciences exactes, et sur-tout la culture de quelques-unes des celles qui servent de préliminaires à l'art de guérir."

${ }^{10}$ Weisz (2006) proposes that specialization began in Paris between 1830 and 1850, particularly in the medical field, during the process of accommodations between surgery, clinical medicine, pharmacy, and veterinary medicine, with the defining of spaces for professional training determined by a labor market which was competitive from the outset, and then the consolidation of specialized curricular trajectories. We 
can complement this hypothesis, indicating that the Cabanis reform (as a movement of linkage between an epistemological structure founded on basic scientific disciplines and analytical pedagogy) was essential to facilitate the training of workers carrying out specialized professional practices.

11 This peculiar idea did not survive Napoleon himself; once the legal competence of the "imperial university" was called into question, starting in 1815 isolated and independent schools, institutes, and colleges withdrew from the unified education system (Charle, Verger, 1996).

${ }^{12}$ The third superior college, the seminary, lost ground during the eighteenth-century republics (Prost, 2009).

${ }^{13}$ In signed articles, official notes, and records from various sites, the biography of Correia Picanço is often summarized in the contents of two texts: a paper presented at the first History Congress of Bahia in Salvador in 1949, and a thesis presented to the second Brazilian Congress of the History of Medicine, in Recife in 1953. Both works summarize a folio published in 1895 by Comendador Antonio Joaquim de Mello in a collection of biographies of famous sons of Pernambuco. The credibility of this information is crucial to more precisely assess the influence of the French model of medical education in the pre-Cabanis era on the early schools of surgery that predated medical education in Brazil.

${ }^{14}$ History records a Brazilian officier de santé, Caetano de Lopes Moura, a mulatto from Bahia and seeker of adventure who served in Napoleon's army as a surgeon and later became a translator and writer, a protegé of emperor Dom Pedro II in Paris (Veiga, 1979).

${ }^{15}$ Chair of clinical surgery at the Rio de Janeiro school of medicine, obstetrician to Princess Isabel, and commissioned by Emperor Dom Pedro II, Saboia made several trips to France between 1871 and 1875 to study the models of medical training used in Europe at that time. See the detailed entry in the Dicionário Histórico-Biográfico das Ciências da Saúde no Brasil (1832-1930) (Sabóia..., s.d.).

${ }^{16}$ Even so, major German influence was seen with regard to incipient research, for example in the famous Tropical School of Bahia, which was intentionally established outside the medical school (Edler, 2009).

${ }^{17}$ A dissertation, generally short and schematic, required to obtain a doctoral degree in medicine (Lima Júnior, Castro, 2006, p.534).

${ }^{18}$ Ruy Barbosa, in his opinion on this education reform bill, praised the concept of university but admitted that it would only be feasible after thorough reforms in the entire Brazilian system of public education (Fávero, 2010, p.25)

${ }^{19}$ The "French USP mission" included young academics (Fernand Braudel, Jean Gagé, Émile Leonard, Paul Arbusse-Bastide, Pierre Monbeig, Émile Coornaert, Roger Bastide, and Claude Lévi-Strauss, among others) who stood out in their respective fields of knowledge (Paula, 2002).

${ }^{20}$ This observation is not limited to the situation after the French Revolution. A century later, the Flexner reform, which was a sectoral reform of medical education intended to complete the cycle initiated by the Humboldt reform (which occurred at the same time as the Cabanis reform, as we have seen above), ended with extensive renovations in the American university system (Almeida-Filho, 2010), making it the standard for academic excellence and promoter of economic growth and cultural transformation of industrial capitalism.",

\section{- it should read:}

\section{“ACKNOWLEDGMENTS}

The author wishes to acknowledge the invaluable contribution by Jacques Salah, professor emeritus of French literature at the Federal University of Bahia and ex-consul of France in Bahia, for revising the translation of original material in French, as well as his generous critical reading of early versions of this text. Thanks also to Luiz Antonio de Castro Santos, who at the time was senior visiting professor at the Federal University of Southern Bahia, for his criticism of early versions of this manuscript and valuable suggestions of historical references.

\section{NOTES}

${ }^{1}$ Cabanis is mentioned 43 times in Naissance de la Clinique (Foucault, 1963), one time for every ten pages; in Folie et déraison (Foucault, 1961), he appears 21 times, on 17 of the book's 550 pages.

2 Which was translated in English as "evidential paradigm" (Ginzburg, 1989). 
${ }^{3}$ Analysis of the Avicennian rupture is beyond the limits of my competence; moreover, except as symbology and discursiveness, little of this rupture is retained in the contemporary context of healthcare.

${ }^{4}$ For this and other citations of texts from non-English languages, a free translation has been provided.

${ }^{5}$ To the extent that Foucault, by promoting dissent within his own project for a cultural history of western thought (which he called a "genealogical approach") disowned himself to a certain extent, I propose to designate any movement toward recovering or eventually renewing the archaeological perspective as a valid, relevant methodological tool for a critical history of healthcare modes as neo-Foucauldian.

${ }^{6}$ As Foucault himself states (1994, p.508): “L'hôpital entant qu'instrument thérapeutique est en effet un concept relativement moderne, puis qu'il date de la fin du XVIIIe siècle. C'est autour de 1760 qu'est apparue l'idée que l'hôpital pouvait et devait être un instrument destiné à guérir le malade. Cela se produit au travers d'une nouvelle pratique: la visite et l'observation systématique et comparée des hôpitaux."

${ }^{7}$ In the original: "L'anatomie seule n'est pour ainsi dire que le squelette de la science; c'est la physiologie qui lui donne du mouvement: l'une est l'étude de la vie, l'autre n'est que l'étude de la mort."

${ }^{8}$ Unfortunately, d'Azyr did not survive the Reign of Terror to see the advance of reforms in French medicine. He was indicted by the feared Comité de salut public for publicly protesting the expulsion of the spirit of revolution in the new Republican Constitution, which was approved by an assembly that excluded the Girondins. He was pursued by popular militias; malnourished and delirious, he died under mysterious circumstances in 1793 (Schmitt, 2009).

${ }^{9}$ In the original: "Un praticien renommé qui doit être indemnisé."

${ }^{10}$ In the original: "Une bonne conduite, des moeurs pures, l'amour de la République et la haine des tyrans; une education assez soignée; pour qu'on soit assuré que les élèves possèdent les premiers élémens des sciences exactes, et sur-tout la culture de quelques-unes des celles qui servent de préliminaires à l'art de guérir."

${ }^{11}$ Weisz (2006) proposes that specialization began in Paris between 1830 and 1850, particularly in the medical field, during the process of accommodations between surgery, clinical medicine, pharmacy, and veterinary medicine, with the defining of spaces for professional training determined by a labor market which was competitive from the outset, and then the consolidation of specialized curricular trajectories. We can complement this hypothesis, indicating that the Cabanis reform (as a movement of linkage between an epistemological structure founded on basic scientific disciplines and analytical pedagogy) was essential to facilitate the training of workers carrying out specialized professional practices.

12 This peculiar idea did not survive Napoleon himself; once the legal competence of the "imperial university" was called into question, starting in 1815, isolated and independent schools, institutes, and faculties withdrew from the unified education system (Charle, Verger, 1996).

${ }^{13}$ The third superior faculty, the faculty of Theology, lost ground during the eighteenth-century republics (Prost, 2009).

${ }^{14}$ In signed articles, official notes, and posts in various sites, the biography of Correia Picanço is often copied from the contents of two texts: a paper presented at the first History Congress of Bahia, held in Salvador in 1949, and a thesis presented to the second Brazilian Congress of the History of Medicine, in Recife in 1953. Both works summarize a folio published in 1895 by Comendador Antonio Joaquim de Mello in a collection of biographies of famous sons of Pernambuco State. The credibility of this information is crucial in order to more precisely assess the influence of the French model of medical education in the pre-Cabanis era on the early schools of surgery that predated medical education in Brazil.

${ }^{15}$ History registers a Brazilian officier de santé, Caetano de Lopes Moura, a mulatto from Bahia and seeker of adventure who served in Napoleon's army as a surgeon and later became a translator and writer, a protegé of emperor Dom Pedro II in Paris (Veiga, 1979).

${ }^{16}$ Chair of clinical surgery at the Rio de Janeiro school of medicine, obstetrician to Princess Isabel, and commissioned by Emperor Dom Pedro II, Saboia made several trips to France between 1871 and 1875 to study the models of medical training used in Europe at that time. See the detailed entry in the Dicionário Histórico-Biográfico das Ciências da Saúde no Brasil (1832-1930) (Sabóia..., s.d.).

${ }^{17}$ Even so, major German influence was seen with regard to incipient research, for example in the famous Tropical School of Bahia, which was intentionally established outside the medical school (Edler, 2009).

${ }^{18}$ A dissertation, generally short and schematic, required to obtain a doctoral degree in medicine (Lima Júnior, Castro, 2006, p.534). 
${ }^{19}$ Ruy Barbosa, in his assessment of this education reform bill, praised the concept of university but admitted that it would only be feasible after thorough reforms in the entire Brazilian system of public education (Fávero, 2010, p.25).

${ }^{20}$ The "French USP mission" included young academics (Fernand Braudel, Jean Gagé, Émile Leonard, Paul Arbusse-Bastide, Pierre Monbeig, Émile Coornaert, Roger Bastide, and Claude Lévi-Strauss, among others) who stood out in their respective fields of knowledge (Paula, 2002).

${ }^{21}$ This observation is not limited to the situation after the French Revolution. A century later, the Flexner reform, a sectoral reform of medical education intended to complete the cycle initiated by the Humboldt reform (which occurred at the same time as the Cabanis reform, as we have seen above), led to profound renovations in the entire university system of the USA (Almeida-Filho, 2010), making it the standard for academic excellence and main promoter of economic growth and cultural transformation of industrial capitalism.".

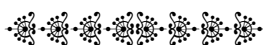

